\title{
Observance against Ambition
}

\author{
The Struggle for the Chancellor's Office at the Real Universidad de San Carlos \\ in Guatemala (1686-1696)
}

Adriana Álvarez

Señor, el dicho Doctor, Don Bartholome de Amezqueta trae perturbado e inquieto al Real Claustro con su ardiente, y cabildoso natural, cuando escandalosamente de arrojos, y valentía con los que lo componen, como constara a vuestra magestad de la información que acompaña a esta. ${ }^{1}$

José de Baños y Sotomayor - doctor of theology, dean of the cathedral, first person to occupy the prima chair of theology, and first chancellor (rector) of the Royal University of San Carlos in Guatemala - wrote the above lines to King Charles II of Spain in 1689 to inform him of the reprehensible behaviour of the professor of law, Bartolomé de Amézqueta. Both crown ministers were fighting about the observance of the legal code. On one side was Baños who - supported by the highest local authorities - strove to remain as chancellor on the grounds that no one else was suitable or available to fill the position and that it was impossible to carry out the annual renewal of the office because there was no competent governing body to do so. On the other was Doctor Amézqueta - who had arrived in Guatemala from Spain about a year before - who pointed out that the permanence of the chancellor constituted a serious offence to the university's legal code. This story shows a legal reality - composed of both a rule and

1 Archivo General de Indias, Sevilla (AGI), Audiencia de Guatemala 136, fols. 267r-267v. 
a praxis - and a conflicting political reality. ${ }^{2}$ Both sides based their arguments upon legal frameworks provided by the statutes of San Carlos, the University of Mexico, and even those of Salamanca, but they also made references to the scholarly reality of Guatemala as well as to those of other Spanish and SpanishAmerican universities. This is a story of an institution whose government would not be "regularised" - that is to say, resolved both formally and legally -, not even by Amézqueta's exile or the death of the chancellor (Baños y Sotomayor).

The main characters of this dispute tried - time and time again - to support their stances with Guatemalan law as well as with the laws of Iberian universities in order to give weight to their arguments. At this point, it is necessary to provide a brief historiographical review of the connections between the foundations of universities on both sides of the Atlantic. Within the shell of the traditional historiography on universities in the Spanish empire, there are some works that have sought to summarise the development of these institutions which generally state that the characteristics of Spanish universities were simply replicated in other locations, and that the universities created in colonial Spanish America under royal patronage were an exact replica of Salamanca, almost as if they were mere branches of it. In 1986, Luis Enrique Rodríguez-San Pedro asserted that Lamberto de Echeverría's historiographical assessment published two decades before - was still generally valid: studies remained local and apologetic. ${ }^{3}$

\section{The Controversial Hold}

Renewed interest in this topic has, however, shown that there were different "models" of universities in Spain and that they underwent changes along time both in theory and practice. In order to construct a history of universities that is not reduced to a mere description of legislation but which instead looks into the specific circumstances surrounding the different periods of their

2 As Thomas Duve writes in the introduction to this volume, "Normative knowledge, however, is not only about theory, ideas, principles, or doctrines. It also comprises practices." Duve, "The School of Salamanca: A Case of Global Knowledge Production".

3 Rodríguez San-Pedro Bezares, La Universidad Salmantina del Barroco, vol. 1, 26. The author of this work has published several bibliographies which include documentary sources. The volume cited here contains a historiographical review. Several of his ideas about the University of Salamanca were produced in a rich historiographical context, as shown in the previous chapter, González González, "Salamanca in the New World: University Regulation or Social Imperatives?" 
development, it is necessary to study them case by case and to always avoid generalisations.

Nonetheless, it is important to mention the significant contributions of authors such as Vicente Beltrán de Heredia and Águeda María Rodríguez Cruz, who edited the cartularios and bularios from the University of Salamanca. Rodríguez Cruz's Salmantica Docet is particularly significant because it provided a broad bibliography up to the year in which it was published and also because its main thesis argued for the so-called "proyección de Salamanca en Hispanoamérica", stating that "Salamanca fue la madre nutricia, directamente, de la gran mayoría de universidades de Ultramar."4 The author dedicated some pages to the Guatemalan case. On the basis of literature about the history of San Carlos, ${ }^{5}$ she re-affirmed one of the foundational myths of this Guatemalan institution: that it was Bishop Francisco Marroquín who first made the request for a university in the 16th century. The prelate had, in fact, requested a chair in grammar for the cathedral, and would - years later - leave an annuity for the foundation of a hall of residence or college. Águeda Rodríguez also identified Salamancan students connected to the development of studies and intellectual life in Guatemala in order to demonstrate the relationship between the bodies of law of San Carlos, Mexico, and Salamanca. Indeed, the constitutions, that is to say the statutes and the regulations of both institutions, ${ }^{6}$ were the models on which the legislation of San Carlos was based, as a comparison

4 Rodríguez Cruz, Salmantica Docet, vol. 1, Xxv. Initially, the author had planned to dedicate a second volume to the university structure and a third one to students of Salamanca who went to Spanish America throughout the colonial period, but this plan was not fulfilled.

5 Several studies on the history of the university were published during the first half of the 2oth century: Martínez Durán, Las ciencias médicas en Guatemala (1941); Castañeda Paganini, Historia de la Real y Pontificia Universidad de San Carlos de Guatemala (1947); Mata Gavidia, Panorama filosófico de la Universidad de San Carlos (1948), Temas de filosofía moderna sustentados en 1785 (1949), and Fundación de la Universidad de Guatemala (1954); Rodríguez Cabal, "Universidad de Guatemala. Su origen-fundación-organización" (1952, 1957); and Lanning, The University in the Kingdom of Guatemala (1955). Most of these works were reprinted between 1976 and 1978, including a translation of Lanning's book.

6 "Los estatutos - como se llamaba al conjunto de normas que rigieron a las universidades americanas - originalmente eran los acuerdos emanados de los claustros, es decir, del gremio. Más adelante, el vocablo terminó refiriéndose a los cuerpos codificados. Así, esos acuerdos, que eran resultado de las decisiones horizontales del claustro, se convirtieron en sinónimo de código jurídico, sancionado por el rey, debido al proceso de centralización del poder del Estado. Por ello, en América [...] fue el monarca el que sancionó la legislación; resultado de ello es la sinonimia de los términos estatutos y constituciones en el nuevo continente." Álvarez Sánchez, "Interacciones y tradiciones: los estatutos de las universidades reales de América", 47 . 
between these bodies of law makes clear. ${ }^{7}$ Despite the modifications that were made to them for San Carlos so that they could be approved, these constitutions, or statutes, were essentially a copy of the Mexican ones, which connects them directly to those of Salamanca.

The Salamancan model and its influence in Spanish America have been studied from new historiographical approaches and in specific researches. Since the 1980s, Mariano Peset has shown that analysing legal documents, such as foundational papers, allows us to appreciate the differences between universities, not only between Salamanca and the American institutions, but also between individual New World institutions. Peset pointed out that, with regard to graduations and ceremonies, the Salamancan traditions were continued in Mexico and Lima - to which I can also add those of Guatemala - even though there were clear differences between them with regard to their governance. ${ }^{8}$

In turn, Clara Inés Ramírez González devoted a chapter to analysing both the scope and the limitations of comparisons between institutions of this kind in her work on the role of the religious orders in Salamanca and Mexico. The author offered a full study of the "projection" thesis of Rodríguez Cruz and also of Peset's proposals, and concluded that "las historias comparadas deben dejar de señalar similitudes, por lo demás lógicas, en el proceso de conformación de las sociedades dependientes o coloniales, para atender a las diferencias, pues son ellas las que permiten entender la especificidad que va adquiriendo cada una de las nuevas sociedades americanas." ${ }^{\prime \prime}$

In the case of Guatemala, part of the historiography of the university accepted the thesis of the Salamancan projection, despite the fact that authors such as José Mata Gavidia (1954) and John Tate Lanning (1955) called this idea into question. Even though there were already several works about the history of this Central American university, they only dealt with its legislation. Despite some research that had consulted documents in the General Archive of Central America and the General Archive of the Indies, the most significant object of study remained the description of the regulations, mainly because there was

7 Álvarez Sánchez, "Interacciones y tradiciones: los estatutos de las universidades reales de América".

8 Peset, one of the pioneers of the renewed interest in universities, carried out significant studies on Mexico and Lima. In the 1980s, he showed the differences between the various institutions which had been inspired by Salamanca, see "Poderes y Universidad de México durante la época Colonial", 57-84 and "La adaptación del modelo salmantino en las fundaciones de Lima y México (1551)", which was originally published in 2002 and then included in a compilation of texts by this author. His complete bibliography has been published in González González, El poder de las letras.

9 Ramírez González, Grupos de poder clerical en las Universidades Hispánicas, vol. II, 153. 
no continuity in these studies after the 1970s. ${ }^{10}$ In the following decade, several of such works were reprinted on the occasion of the triennial, but the festive atmosphere was not enough to encourage historians to carry out new studies. Progress in the analysis of barely-used documentary sources and in the rereading of those that were already known which was made at the beginning of the 21st century has allowed us to better understand this university. As a result, this chapter shows San Carlos more as a counterexample of Salamanca - and even of Mexico - than as its faithful daughter. References to Salamanca - to its legislation and its historical development - will help explain part of this process.

Therefore, we shall examine the controversial permanence of the first chancellor (rector) of San Carlos in his position and the constant complaints of a lecturer who contested the resulting lack of compliance with the regulations. This evinces - as Víctor Tau Anzoátegui has pointed out with regard to the case of the assignment - the legal "dissimulation" with which the patron and the vice-patron of the university behaved.1 This dispute continued throughout the second decade of the university's existence at a time when there were already schools and chairs and the first generation of philosophers (filósofos or artistas) had graduated, even though the internal government had not been appointed in accordance with the regulations. In order to thoroughly understand the confrontation, it is necessary to review the arguments that were presented -making appeal to the Salmantine legislation as well as to the reformed constitutions (hereafter statutes) of San Carlos-, and the protagonists of the dispute, by analysing the written records which explained both how the institution worked and the way in which its legislation was to be applied.

The relevance of this episode in the history of the studium generale - i.e. royal universities - lies in the fact that it can be considered as sufficient proof that legislation is not able to explain by itself a process of this kind, despite

10 Castañeda Paganini, Historia de la Realy Pontificia Universidad de San Carlos de Guatemala; Rodríguez Cabal, "Universidad de Guatemala: su origen-fundación-organización”; Mata Gavidia, Fundación de la Universidad de Guatemala, 1548-1688.

11 Víctor Tau Anzoátegui has carried out several studies both on the casuistry and the dissimulation or legal tolerance to which the monarch and his ministers turned in order to maintain control over his territories, even though this meant an apparent contradiction to the ruling order. The author pointed out that this concept already existed in the 17th century, and defined it as "tolerancia provisional", which implied that even though an authority knew of an irregular situation, he also acknowledged the impossibility of solving it. This dissimulation remained in Spanish law and was also applied in America. Tau Anzoátegui, "La disimulación en el Derecho Indiano", 227. For more on the plurality of the law in America, see ¿Quéfue el Derecho Indiano? and Casuismo y sistema, both by the same author. 
being the cultural translation of both the university regulatory tradition and legal pluralism, ${ }^{12}$ a result of the diversity of the peoples in Spanish America. ${ }^{13}$ The permanence of the chancellor was the result of local social dynamics, as well as of the power groups established under royal patronage, and of the legislation that the monarch had passed for San Carlos. Royal patronage and the presence of the monarchy within universities, both in Salamanca and New Spain - perhaps more markedly in the latter - allowed the sovereign and his representatives not only to pass laws but also to ensure their enforcement.

The University of Salamanca of the ancien régime was the benchmark which the Crown used when, during the 16th and 17th centuries - and projecting throughout the 18 th century -, it intended to establish a studium generale. The institution had a government composed of the chancellor and the councils. ${ }^{14}$ Both positions, at the individual and corporate levels, were to be renewed on an annual basis with the former following the principle of temporal alternation. This model was adapted for the four royal universities that were founded to offer academic degrees in the Indies: Lima, Mexico, Guatemala, and

12 Cultural translation is a concept from anthropology that authors such as Peter Burke have been using for some years in order to study the formation of communities in the modern age. In the case of royal universities, the translation of regulations to local institutions implied a process of cultural translation from a model, that of Salamanca. Universities in America first adapted the legislation in written form to their contexts; however, they played a key role when applying the regulatory body of universities. See Burke and Hsia (eds.), Cultural Translation in Early Modern Europe and Duve, "The School of Salamanca: A Case of Global Knowledge Production".

13 Matching other authors, Víctor Tau Anzoátegui stated that "El gobierno de las Indias requería un orden jurídico abierto y plural, maleable y dinámico que, sin descuidar sus principios rectores, ofreciese 'válvulas de escape' para adecuar la aplicación de las normas."; see "La disimulación en el Derecho Indiano", 231.

14 The University of Salamanca had five different types of council (claustro): plenary, of councillors (consiliarios), of deputies (diputados), of doctors and masters, and of primicerii, although the latter, which was made up of doctors and lecturers, gradually lost its political presence which led to its activities being reduced to matters of protocol. In turn, the plenary council became stronger and the preponderance of the doctors over the students also increased with time, Rodríguez-San Pedro Bezares, La Universidad Salmantina del Barroco, vol. I, 342. This hierarchical tendency was replicated in the foundations of universities in New Spain. Mexico and Guatemala only had the first three types of council. Councillors were in charge of choosing the chancellor (rector) and providing teachers for the chairs until 1676 when the voting council was created, though members continued to be responsible for declaring a chair to be vacant. Deputies supervised the estate, while the plenary council dealt with all other institutional issues and those upon which the other two bodies had failed to agree. Álvarez Sánchez, "Los libros de claustros como fuente para estudiar la vida universitaria", $387-401$. 
Guadalajara. ${ }^{15}$ The chancellor in the American universities had to be a doctor, unlike in Salamanca where the internal balance of power was based upon the scholarly representation of the chancellor, the Maestrescuela, and the councils. ${ }^{16}$ The fact that the chancellor in Salamanca was a student, and not a doctor, did not rid the university out of conflicts, because, as well as maintaining the geographical alternation, the candidate had to have enough means at his disposal for the expenses of the position - dinner parties and feasts were quite usual -, which is why the chancellors were usually the sons of nobles with a title. Another factor was the young age of the students, who would usually declare themselves unfit to carry out the obligations of the chancellor: visiting the chairs and the archives, checking the accounts, etc. All this complicated the task of appointing a chancellor every year. ${ }^{17}$

\section{$3 \quad$ New Foundations for New Establishments}

In the same way as happened in the European territories of the Spanish Crown, the religious orders founded residence halls or colleges in which scholarly courses were also taught, some of which had the privilege of granting degrees. Therefore, the monarch ensured his right of patronage over the universities by allowing teaching to continue at colleges but not confer academic degrees. ${ }^{18}$

During the second decade of the 17th century, a number of proposals were presented to establish a university in Guatemala using resources that had been bequeathed by the first bishop, Francisco Marroquín, for the establishment of

15 Álvarez Sánchez, "Interacciones y tradiciones: los estatutos de las universidades reales de América". In the case of Guadalajara, a chancellorship lasted for two years.

16 Peset, "Poderes y Universidad de México durante la época Colonial".

17 In his long study on this university, Luis Enrique Rodríguez-San Pedro Bezares explained how the statutory requirements to be a chancellor complicated this appointment. The geographical alternation involved appointing a student who had been born in Castile one year and someone who had been born in León the following. Rodríguez-San Pedro Bezares, La Universidad Salmantina del Barroco, vol. I, 353-36o. Neither Mexico nor Guatemala used this geographical alternation model, which was replaced, in both cases, by the alternation of clergymen and laymen.

18 The monopoly of conferring degrees has been extensively studied by Pavón Romero, Universitarios en la Nueva España. He started a systematic graduate index, the results of which have been presented in theses, chapters, and articles. In the case of Guatemala, Lanning (The University in the Kingdom of Guatemala) dedicated some pages to the graduates, particularly with regard to the statutory requirements. A detailed study can be found in Álvarez Sánchez, "Los grados de la Real Universidad de San Carlos de Guatemala", $193-216$. 
a college, which, it transpired, was ultimately not possible. By the 1670s, the project of a university was a matter of controversy between the Jesuits and the Dominicans. The former stated that their college was already, de facto, a university, as they were able to confer academic degrees; the latter, who also enjoyed the privilege of conferring degrees, chose to adhere to the project that requested the foundation of a studium generale under the sovereign's patronage. ${ }^{19}$

The royal charter for San Carlos was issued in January 1676 but courses did not begin until 1681 due to the complicated process for selecting lecturers, after which courses were offered in almost every faculty. It started with Dominican friars in the chairs of the arts and theology, law was taught by graduates from Mexico and Lima, and medicine was taught, albeit without a physician, because even though a Mexican obtained the position, he never arrived in the city. Moreover, two more chairs for indigenous languages (Cakchiquel, and Mexican or Pipil/Náhuat) were created without a special school, but only the former had a lecturer in the first few years. All of the lecturers held temporary positions at the command of the king as a result of the complex process of selection undergone by the candidates in $1677 \cdot{ }^{20}$

This way, activities began at a university whose patron still had to pass its legislation. For many years, its legal framework was that of Mexico, which had been devised by Juan de Palafox y Mendoza - which was in turn based on that of Salamanca - and passed in 1668 , and was still applicable at that time. ${ }^{21}$ Until 1685, the Guatemalan institution was governed by a board of local authorities and administered by its superintendent, the judge of the Audience [oidor] Francisco de Sarasa y Arce. By royal decree of 9 June 1686, Charles II passed the regulations and constitutions that this superintendent had prepared "para su mejor gobierno" and sent to Spain, under the king's orders, five years before. ${ }^{22}$

19 Álvarez Sánchez, Patronazgo y educación.

20 The call to fill the position of chairs was made public in Guatemala, Mexico, and Puebla but the selection was made in the capital of Guatemala. The results were challenged both by crown ministers and by the applicants, and so the king determined that these positions were to be temporary. AGI, Guatemala 137, fols. 132r-149r. Royal document of 6 June 168o, Archivo General de Centroamérica, Guatemala (AGCA), A1, leg. 1885, exp. 12245, also Lanning, Reales Cédulas de la Realy Pontificia Universidad de San Carlos de Guatemala, 39-43.

21 The statutes of Palafox have recently been edited, Palafox y Mendoza, Constituciones para la Real Universidad de México. There is a copy of this body of law in the General Archive of Central America which was printed in 1698, AGCA, A1, leg. 1888, exp. 12298.

22 Royal decree of 9 June 1686. AGCA, A1, leg. 1882, exp. 12236, fols. 56. See Lanning, Reales Cédulas de la Realy Pontificia Universidad de San Carlos de Guatemala, 49-51. 
On the same day, this patron issued many other royal decrees in which he made appointments and entrusted the authorities to charge rents for the properties and revenues belonging to the institution. Two of these appointments were issued in favour of Doctor José de Baños y Sotomayor: one assigning to him the prima chair of theology, ${ }^{23}$ and the other the office of chancellor. Thus, Baños would enjoy the privileges held by professors in Mexico and Lima and, according to the king, "sin que os falte cosa alguna cumpliendo vos por vuestra parte con lo dispuesto y ordenado en esta razon por los estatutos y constituciones de la de Guatemala." 24

For the appointment of the chancellor, the monarch commanded the ministers of the Real Audiencia to appoint Baños to the position and to take his oath, also ordering Baños in the document "y exerçais por el tiempo estatuido por las dichas constituciones, y que durante el os ayan, y tengan por rector de la dicha Univerçidad y que goceis todo lo que como tal os tocare y deviereis y pudiere gosar."25 On 5 November of each year, the councillors were to meet in order to start the process of choosing a new chancellor by presenting the candidates for the first scrutiny or assessment. They were to meet again three days later to examine other candidacies - if there were any - and, finally, they were to meet every 10 November, right after the Mass of the Holy Spirit, to choose a new chancellor by means of a secret vote that has to be settled by a simple majority. ${ }^{26}$

The exact date on which the appointment document arrived in Guatemala remains veiled, but it is known that Baños took up his position on 18 October 1686, less than a month before the following election. ${ }^{27}$ The new chancellor and part of the local government assumed that the chancellorship was to continue until November of the following year, mainly because the councils had not yet been formed. In November 1686, the Real Audiencia allowed the chancellor

23 Royal decree of 9 June 1686. AGCA, A1, leg. 1883, exp. 12237, fols. 73-73v. Lanning, Reales Cédulas de la Real y Pontificia Universidad de San Carlos de Guatemala, 59-61. In 1677, Dominican friar Castillo obtained the chair after confronting opposition, AGCA, A1, leg. 1898, exp. 12442. The appointment of Chancellor Baños meant Castillo's expulsion from his chair.

24 Royal decree of 9 June 1686, AGCA, A1, leg. 1883, exp. 12237, fols. 73r-73v.

25 AGCA, A1, leg. 1883, exp. 12237, fols. 72r-72v. Lanning, Reales Cédulas de la Realy Pontificia Universidad de San Carlos de Guatemala, 67-69.

26 In the case of a tie, the outgoing chancellor would be the one to make his vote public, and "por quien huviere votado sera rector" ["for whoever he has voted, shall become the chancellor"]. Sarasa y Arce, Estatutos y constituciones Reales de la Regia Universidad de San Carlos de Goathemala, II, 3. AGI, Guatemala 136, fol. 322r. 
to present a list of professors from whom the eight members of the council and the five finance deputies of the university were to be chosen. These were significantly fewer in number compared to Salamanca, where there were eight members of the council and 22 deputies. This was due to the different sizes of the universities: the adaptation of the model in America meant a reduction in the number of people who would take decisions in accordance with the ever greater concentration of royal power. ${ }^{28}$ In order to do this, after consultation with the monarch, the degrees granted by the studium generale in Mexico and Lima, and by the Jesuit college in the city, were recognised, and even friars who did not have university degrees were accepted on the condition that they committed themselves "que luego que llegue la Bula Pontificia se graduen sin pompa y secretamente por ser notoria su suficiencia”. ${ }^{29}$

The board gathered on 16 December to choose the first members from the members of the council who were to complete the university government. ${ }^{30}$

28 The eight positions as members of the council were to be distributed among the students, two for each of the "nations" that had been acknowledged after a regionalisation: the Kingdom of Leon; Galicia, Astorga, and Portugal; New Castile, Andalusia, and the diocese of Plasencia; Old Castile, Navarre, the Crown of Aragon, and foreign realms. In the 17th century, a new region was created exclusively for Portugal, keeping its representation in the second one. Rodríguez-San Pedro Bezares, La Universidad Salmantina del Barroco, vol. I, 366-374.

29 On 11 December 1686, the chancellor suggested the incorporation of 19 (four doctoral, two master's, six graduate, and seven bachelor's) degrees, also accepting eight friars as incorporated, four of whom were Dominican and the other four Mercedarian. AGCA, A1, leg. 1889 , exp. 12300 , fols. $5{ }^{r-7 r}$, the quotation can be found in fol. 5 v. Incorporation (incorporación) was an academic, administrative, and legal process of recognising and regularising the degrees issued by other universities, assimilating them to the level of their own. 1) Antonio de Salazar, graduated on 12 July 1673 , from the Societas Iesu; doctor of theology, archdeacon, and comisario of the Holy Crusade, Guatemala, AGCA, A1, leg. 1940, exp. 12866. 2) Pedro de Estrada, Dominican Friar. 3) Bernardino de Ovando, Jesuit graduate, master, clergyman, and synodal examiner of the bishopric, AGCA, Al, leg. 1889, exp. 1230o. According to the chancellor, Bernardino de Ovando and Ignacio de Armas were graduates of the Jesuit San Lucas College. However, Carmelo Sáenz de Santa María mentioned that the corresponding degrees have not been found in the list of graduates from this institution, Sáenz de Santamaría, Historia de la educación jesuítica en Guatemala, 137-138. 4) Rodrigo de Valenzuela, Mercedarian, official assessor (calificador) of the Holy Office. 5) Ignacio de Armas Palomino, master, rector priest (cura rector) of the cathedral, and synodal examiner of the bishopric. 6) Nicolás Roldán de Toledo, graduated from the Society of Jesus and received his degree from Bishop Payo Enríquez de Rivera in a ceremony between 1669 and 1670, AG CA, A1, leg. 1940, exp. 12865; Irungaray, Índice del Archivo de la Enseñanza Superior de Guatemala, 228; AGI, Audiencia de Guatemala 137, quoted in Sáenz de Santa María, Historia de la educación jesuítica en Guatemala, 120. 7) Pedro López Ramales held a bachelor's degree from the Jesuit College of Guatemala, Sáenz de Santa María, Historia de la educación jesuítica en Guatemala, 143, rector priest of the San 
Every one of them were connected to the chancellor in one way or another, being either graduates from the Jesuit college or friars, and they all had appointments within the Church's administrative apparatus at the local level. For decades, the Society of Jesus had pushed for the Crown and local authorities to recognise its college as a university. Even some of the bishops who granted degrees to the doctors from this institution did so under protest, given that the Jesuits lacked the indispensable royal approval. Nevertheless, until that time, this college had granted the most degrees in Guatemala, along with the college of the Dominican convent, which strove to attain that same privilege but was unable to gain it when the lectures in its chairs were abolished in $1631 .{ }^{31}$ These appointments were part of Baños's strategy: he needed to buy time in order to find a way to remain in his position, and he managed to do so because the members of the council, all of whom had graduated from the Jesuit college, slowed the process down.

With regard to the finance council, the appointments made by Baños were professors and, even though the deputies were supposed to have tenure according to the regulations, ${ }^{32}$ they were, in fact, temporary at the time. Among them, we were unable to find the arts professor, although we did find an instructor of a chair with no school, a certain González de Maeda. ${ }^{33}$

On 10 January 1687 , all the members of the council took an oath before Chancellor Baños, which concluded the establishment of the councils. In spite

Sebastian parish, and interim professor of arts. 8) José Fernández Parejo, bachelor in medicine and protomedic of the city. Meeting of 16th December 1686, AGCA, A1, leg. 1889, exp. 1230o, fols. 8r-14r, Pardo, Efemérides de la Antigua Guatemala, 80-81. The regulations designated eight members for this council, Sarasa y Arce, Estatutos y constituciones Reales de la Regia Universidad de San Carlos de Goathemala, IV, 39.

31 Regarding the conflict between the two institutions and the development of their respective colleges, see Álvarez Sánchez, Patronazgo y educación, 29-39. Regarding the Dominican College, see Álvarez Sánchez, "El Colegio de Santo Tomás de Aquino de Guatemala", 43-66.

32 Sarasa y Arce, Estatutos y constituciones Reales de la Regia Universidad de San Carlos de Goathemala, viI, 6o.

33 The deputies were the following: 1) Diego de Rivas, Mercedarian, temporary vespers professor of theology, and Inquisition assessor. 2) Antonio Dávila Quiñones, graduate of the University of Mexico, temporary professor of Instituta, and attorney (abogado) to the Real Audiencia. 3) Lorenzo Soriano de la Madriz Paniagua, graduate of the University of Mexico, temporary holder of the principal chair of Law (prima de leyes), attorney to the Real Audiencia, and general government advisor. 4) Baltasar de Agüero, graduate of the University of Lima, temporary holder of the main chair of canon law (prima de cánones), and attorney to the Audiencia. 5) Lorenzo González de Maeda, bachelor, temporary professor of the Mexican language - by direct appointment of the chancellor -, and clergyman. 
of this, on 3 November the same year, the chancellor, who was also the dean of the cathedral at the time; the maestrescuela, who was also the head of the cathedral; and the bishop of Guatemala had a meeting and called themselves the "real claustro de la universidad de San Carlos". In this "royal council", they set forth the problem posed by the renewal of the chancellorship, due to the fact that

[...] no haverse formado, ni criado todavia el dicho claustro de consiliarios respecto de no haver sujetos en quienes concurran todas las calidades que requiere su magestad en los nuevos estatutos [...] y por no haver venido la bula de su santidad para graduar e incorporar sujetos de que se a de componer y formar. ${ }^{34}$

This unusual - to say the least - board adapted the appointments of the members of the council and the chancellor following the arrival of a papal bull that had been issued previously and which, only a year before, had not been deemed necessary for the incorporation of the local graduates who would afterwards be appointed as members of the council. In the minutes of this meeting, the three ministers stated that their decision complied with "efecto de comensar el govierno y dar expediente a los negoçios de ella y dar por entero cumplimiento a lo dispuesto y ordenado por su magestad en dichos estatutos y constituçiones". ${ }^{35}$ According to the regulations, the new members of the council were to be chosen in the plenary council: statute four of title two stated that, after appointing a chancellor, the members of the council of the previous year were to gather in the plenary council. This meant the attendance of all the doctors in order to select those who would constitute this government body, the members of which were to take turns in their positions in accordance with their capacity and the rank of those in office. ${ }^{36}$

34 AGI, Guatemala 136, fol. $365 \mathrm{v}$.

35 AGI, Guatemala 136, fol. 365 r.

36 The regulations stated that there had to be eight Members of the Council: four doctors or masters, one master with no other higher degree, and three probationary bachelor teachers. All of them were to be graduates of different faculties and they were appointed under the alternation principle with regard to both the faculty and the status of the graduate (a clergyman or a layman). This distribution by faculties did not correspond to the regional representation that existed in the configuration of the Salamancan Council. Regarding the restrictions on being appointed as a member of the council, both in Guatemala and in Salamanca, they sought to prevent repetition in a position, ensure the alternation, and define the duties of the council. On the Salamancan case, see title II of the Estatvtos hechos por la mvy insigne Vniversidad de Salamanca. Recopilados nuevamente por su comisión. 
The three ministers argued that it was impossible to appoint a chancellor due to the fact that statutes eight, ten, and 11 stated that whoever occupied the position had to be a doctor, someone who had properly graduated in the same university, or in another one and had incorporated that degree, with the aforementioned alternation between clergymen and laymen ${ }^{37}$ On this occasion, the council decided that it was, in fact, necessary to wait for the arrival of the papal bull in order to be able to carry out a new incorporation of graduates and thus be able to appoint the members of the council. With regard to the importance of the Holy See in the history of the university, we need to consider the fact that in universities such as Salamanca, pontifical power was gradually replaced by royal power from the time of the Catholic Monarchs until "la vinculación de las universidades al Papado se torna cada vez más alejada y simbólica". ${ }^{38}$ In spite of this, both in Spain and in America, universities maintained relationships and connections not just with the Holy See - under the vigil of the Crown - but also with the highest church, civil, and aristocratic authorities. This is why this council referred to the papal bull, appealing to the papal ruling in order to validate the degrees.

Despite the impediment set forth by the ministers, they decided that they were in a position to appoint a chancellor. Their choice was one of the new lecturers from the metropolis, Bartolomé de Amézqueta y Laurgáin, who was currently in the province of Honduras and travelling to Guatemala. ${ }^{39}$ The new problem was the lack of a lay doctor in the city: the doctors who had been acknowledged the year before had all been theologians, and the council presumed the incorporation of Amézqueta's doctoral degree, which had been authorised by the king himself when he had granted him his appointment as lecturer.

Until the new chancellor arrived in the city, the ministers decided to appoint a temporary one: Lorenzo Pérez Dardón, the maestrescuela, who filled this position because - according to the ministers - he belonged to "este claustro nuevamente criado por su magestad", even though he only held a bachelor's degree and would not receive his doctorate in theology until February the following year. ${ }^{40}$ In this way, the aspirations of Pérez Dardón were also curtailed

37 AGI, Guatemala 136, fol. 367 r.

38 Rodríguez-San Pedro Bezares, La Universidad Salmantina del Barroco, vol. I, 292.

39 A copy of the minutes of these meetings was sent to the Council of the Indies, which has allowed the reconstruction of this process. AGI, Guatemala 136, fols. $364 \mathrm{v}-367 \mathrm{v}$.

40 AGCA, A1, leg. 1940, exp. 12874. 
owing to his lack of a doctoral degree. ${ }^{41}$ The vice-patron (Jacinto Barrios Leal) of the university was notified of all this. ${ }^{42}$

The appointments of the trustee (sindico), the secretary, and other officers were the main issues dealt whitin the university councils, not to mention the issue of the chancellorship. Baños had set forth some arguments based upon both the patron's - that is, the king's - orders, and the approval of the vice-patron in order to prevent his authority from being called into question. However, Amézqueta's arrival was to cause a conflict that would involve the highest authorities in the captaincy territories, and even reached the monarch through the Council of the Indies.

By the end of December 1687, the papal bull finally arrived in the city. ${ }^{43}$ This did not go unnoticed by Baños, who decided to make use of it to recover his position as chancellor with the support of local public powers by means of a "second foundation" of the studium generale. This was how the confrontation between Amézqueta and Baños began, and it was a conflict that would be characterised by a constant exchange of legal arguments between its protagonists who would polarise the standings of the local elite through mutual hostility that was expressed everywhere.

Baños began by passing a query on to the vice-patron: according to him, during the time he had been chancellor, he had not been able to enjoy "las honras y emolumentos" that the king had granted him by naming him the first chancellor, for an university which "no estuvo perfecta en su fundaçion" until the bull effectively arrived. In response, and based upon the opinion of the attorney of the Real Audiencia, its president ordered him to be restored to the position of chancellor due to the fact

41 AGI, Guatemala 136, fol. $367 \mathrm{v}$.

42 The captain general of Guatemala, who was both simultaneously the president of the Real Audiencia and the governor, was the highest authority in these territories, which is why he served as the vice-patron of the university. Throughout the year 1686, there were two vice-patrons: general Enrique Enríquez de Guzmán and grand master Jacinto Barrios Leal. Although vice-patrons in the same year, it is known that the first acts of the university were passed by Enríquez de Guzmán and that, months later, Barrios Leal took office and became president of the Real Audiencia.

43 In 1595, the bull for the Royal University of Mexico had been held back by the Crown because it assumed that it did not abide by the royal patronage because the pontiff had surpassed his privileges and the Crown ministers had not carried out the corresponding corrections. In contrast, in the case of San Carlos, the bull was passed and taken to the city, though - according to Enrique González - the adjective "pontifical" simply granted an honourable note to the upper hierarchy of its patrons. González González, “ ¿Era pontificia la Real Universidad de México?", 53-81. 
[...] que el retorato de que su magestad hiço merçed al dicho doctor [...] durase solo hasta el dicho dia dies de noviembre de este presente año; pues esta constituçion habla en terminos haviles y posibles de poderse elejir dicho dia nuevo rector con cuia elecçion sese el ofiçio de el primero. ${ }^{44}$

Therefore, his appointment must be made effective again from the very moment the university was "nuevamente fundada" by the arrival of the papal bull. This implied that his new term as chancellor was to last until 1o November 1688. By means of a decree issued on 3 January of the same year, the president of the Real Audiencia ordered that the councils of 3 and 10 November of the previous year - in which Amézqueta had been appointed as chancellor and Pérez Dardón as temporary chancellor - be annulled, and that the "primeros consiliarios" (first members of the council) be appointed. ${ }^{45}$ The appointments of the members of the council and the members of the finance council had not been renewed either and would be annulled just as quickly.

The bull was translated into Spanish and read in public on 15 February 1688. Baños was re-instated as chancellor until October, when he decided to leave his position. Citing his many occupations along with other just reasons, he passed on a new query to the vice-patron, in which he stated the impossibility of appointing members of the council because there were no "sujetos haviles que puedan ser electos consiliarios para proseder a la elecçion de rector". In response, the president of the Real Audiencia, as well as re-asserting the implicit alliance between Baños and the authorities of the Captaincy of Guatemala, argued that this would be beneficial to the Crown, "no ha lugar el admitir dicho desistimiento por ser tan del serviçio de Dios nuestro señor, vien de la causa publica y agrado de su magestad continue el, exersa su rectorado con el mismo desvelo y aplicacion que siempre." 46

A couple of days later, Amézqueta was involved in an argument within the council which would subsequently be used by the chancellor in a secret report against the professor, which he sent to the Royal Council of the Indies. The reason for Amézqueta's disagreement with the council was the recusal that the Bachelor Ignacio del Mármol had presented against Doctor Pedro de Ozaeta y Oro, a lecturer in canon law. Ozaeta was born in Quito, studied in Salamanca,

44 Query and reply of 29 December 1687, AGI, Guatemala 136, fols. 334r-336v.

45 Annulment of the councils of 30 December 1687 , and decree of the vice-patron of 3 January 1688 , AGI, Guatemala 136, fols. $337 \mathrm{r}-338 \mathrm{v}$.

46 The query is from 5 October and the decree from two days later, AGI, Guatemala 136, fols. $338 \mathrm{v}-34$ or. 
and had returned to the Indies with Amézqueta, and even though there does not seem to have been a previous conflict between them, Ozaeta soon submitted to the interests of Baños. ${ }^{47}$ In this argument, Amézqueta said that Ozaeta had a "buen natural (tan opuesto a la verdad, como amigo de chismes, con que logra introducción y suposizion descomponiendo a otros)". The argument continued outside the schools, where they both met. According to Amézqueta's version, they had cordially come to an agreement, but Doctor Miguel Fernández, the third professor who had travelled with them to Guatemala, ${ }^{48}$ appeared and provoked him with offensive statements. According to Fernández, Amézqueta threatened him with the "espadín de uno de los dos muchachos" who were with him. This was denied by the professor of law. ${ }^{49}$

\section{5} The Fight over the Chancellorship: Showdown

As a result of these incidents, the chancellor began a trial against Amézqueta on 10 November, the very day that the new chancellor's appointment was to take place, according to the regulations. Baños stated in the minutes of the meeting that, in the council meeting of 9 October of that year, the professor "prorrumpio con palabras y voçes mal sonantes tirando a provocar y desafiar al dicho doctor don Pedro de Ozaeta, quien con alegre semblante, y mucha cordura, procuro sosegarlo". ${ }^{50}$ The testimonies of three men who declared that they had been present during the confrontation were added to the document. The first of them, Nicolás de Lorenzana, scribe of the king and the Audiencia, who served as a secretary to that council meeting, stated that Amézqueta had entered the chapter hall with

[...] dos criados españoles que el uno de ellos era hombre hecho, el qual llevaba en esta ocaçion espada, no trayendola en otras; asimesmo llebo en esta dicha ocaçion otro criado negro esclavo suyo desarmado, y haviendose juntado con el doctor don Pedro de Ozaeta para entrar en dicho

47 AGI, Contratación 579o, L. 3, fols. 103r-103v and 107v-108v; AGI, Indiferente General 135 , N. 25 .

48 AGI, Indiferente General 127, N. 105.

49 Council meeting of 9 October 1688 , AG I, Guatemala 373 , fols. 344v-346r. The description of these incidents can be found in a long letter that Doctor Amézqueta sent to the king in 169o, which was received on 5 December that same year. In almost 40 pages, the professor explained in detail the political relations that Chancellor Baños had with the rest of the council and with the local authorities. 
claustro vio este testigo con el semblante demudado al dicho doctor don Bartholome de Amesqueta y en el dicho claustro, provoco con mucha descompostura a los señores del procurando el señor rector, con tocarle la campanilla repetidas vezez a ataxar sus exesos. ${ }^{51}$

José Collarte and the high janitor (bedel mayor) Luis Arias Maldonado, the other two witnesses, did not distance themselves from this statement or from the statements of Professor Ozaeta and Doctor Baños. All the information gathered was sent to the Royal Council of the Indies on 14 November 1688, while Baños y Sotomayor remained in the position of chancellor, which he had tried to leave less than a month before.

Coincidentally or not, on the following 18 November, the friars Agustín Cano (Dominican), Juan Bautista Álvarez de Toledo (Franciscan theologian and professor of the chair of Scotus), and José de Morales (Mercedarian and holder of the chair prima de artes) received their doctorates from Chancellor Baños. ${ }^{52}$ This becomes all the more interesting if we take into account the fact that these men were all members of the three most powerful orders at the local level, with the exception of the Society of Jesus, and that Baños's relations with the religious orders had not been particularly cordial in the past, right from his time at the cathedral and even before he had attained the position of dean of the cathedral and chancellor. Cano had even been expelled by Baños from the chair prima de artes as soon as he became chancellor.

This internal process allowed the chancellor to take legal action against Amézqueta without him being aware of it. In January of the following year, the professor of law sent a letter to Baños insisting on and demanding compliance with the regulations. In it, he reminded him that, according to the Statute 81 , an ordinary council was to take place on the last Saturday of each month, under the penalty of ten pesos which was to be paid by the chancellor for every time that it did not take place, and requested him to summon the council for 29 January. The chancellor stated that it would not be possible to convene the council on that day since the ceremonies to grant the degree of Bachelor of Arts to Tomás de Arrivillaga - a cleric and a deacon - were due to take place then, and that the following days of the month were dies feriati. In anticipation, Baños ordered the janitor, Arias Maldonado, the same man who had testified against Amézqueta, to summon the council for the following Tuesday. ${ }^{53}$

\footnotetext{
51 Testimony of 11 November 1688, AGI, Guatemala 136, fol. $269 v$.

52 AGI, Guatemala 154.

53 Request and decree of 28 January 1689, AGI, Guatemala 136, fols. 294r-294v.
} 
The council met on 1 February, and it was composed of the chancellor (Baños), the maestrescuela, and Professors Amézqueta (law), Ozaeta (canon law), Fernández (medicine), Agustín Cano (vespers of theology), Juan Bautista Álvarez de Toledo (Scotus), and José de Morales (prima de artes). ${ }^{54}$ Doctor Amézqueta planted the seed of doubt over Baños's permanence in the chancellorship and whether the renewal of the position should have taken place on the previous 10 November, as established by the legislation. The argument did not prosper in this sense, even though some of those present did express their doubts regarding whether the decision on the matter was to be that of the vice-patron Jacinto Barrios Leal or of a superior court: the Royal Council of the Indies. They agreed, however, that this was not a matter that should be dealt with in the council, and others declared themselves in favour of Baños continuing as chancellor.

The first man to support Baños continuing as chancellor was Lorenzo Pérez Dardón, who avoided conflict by stating that there was nothing whatsoever in the regulations to stop Baños from continuing to occupy the position of chancellor, and that, in any event, the debate should have been initiated in the council meetings of the previous year, in which queries that were to be put to the monarch were drafted. In order to resolve the question, the maestrescuela stated that, in his opinion, it was necessary to vote in accordance with statute go of the regulations, that is to say, by a simple majority if it was a matter of justice, or by unanimity if the matter was considered to be a question of pardon. Hypothetically, Baños could have argued in favour of it being a matter of justice since he could have easily managed to obtain a simple majority, whereas for Amézqueta, it was more convenient that it was dealt with as a matter of pardon, as a unanimous vote against his stance would have been highly improbable. The argument was re-enforced by alluding to the will of the highest authority in the Guatemalan Captaincy and to that of the king himself.

Pedro de Ozaeta, for whom that meeting was most significant, was the second person to vote. According to the canonist, the vice-patron should be consulted on this specific matter, given the incomplete process of the foundation of the university. Ozaeta even declared that Doctor Baños was to continue as chancellor "hasta que la Univerçidad este en forma o conste lo contrario del real animo de su magestad", 55 maintaining the chancellor's permanence upon the express will of the monarch, of Governor Enrique Enríquez de Guzmán, and of his successor, Jacinto Barrios Leal, the vice-patron at the time.

\footnotetext{
54 Copy of the minutes of the council meeting of 1 February 1689, AGI, Guatemala 136, fols. $342 \mathrm{v}-346 \mathrm{v}$.

Vote of Doctor Pedro de Ozaeta, AGI, Guatemala 136, fols. 344v-345r.
} 
The next man to cast his vote was the vespers professor of theology, the Dominican Agustín Cano. He stated that he was in favour of Doctor Baños remaining as chancellor because there had not been an appointment of councillors - as previously mentioned, the councils had not been renewed either-, to which he added the decrease in the number of possible candidates in the city, and the need, in any case, to consult the vice-patron of the institution on that specific matter. He had been part of the foundational process from 1677 because he had undergone a selection by public examination and had obtained the chair prima de artes. Cano had not been present on many occasions because of his duties as a provincial representative of the order, which would eventually cost him his position as a temporary professor of the chair at the hands of Doctor Baños as soon as he became chancellor. ${ }^{56}$ The Franciscan friar Juan Bautista Álvarez de Toledo, lecturer of Scotus, was of the opinion together with friar José de Morales, a professor of arts- that because there were no "able" men who were available to be councillors, they should respect the decrees of the attorney of the Real Audiencia, namely, that Chancellor Baños should continue in the position. Finally, the physician Miguel Fernández shared Cano's opinion. In this way, the legal irregularity of Baños continuing as chancellor was acknowledged. It was specified, however, that there was no premeditation in the actions of the authorities who allowed it because the situation warranted the temporary suspension of the regulations.

Amézqueta was not deterred: he asked the president of the Audiencia to annul the decisions taken at the meeting of the council and for the election of a new chancellor to take place. ${ }^{57} \mathrm{He}$ asked the secretary of the university to make him a copy of the minutes and the documents that had been presented, ${ }^{58}$ which the officer in San Carlos was made aware of by his assistant, Juan Vázquez de Molina. ${ }^{59}$ On 12 February, at the request of Amézqueta, there had been a summons for a council meeting in order to appoint the finance deputies, since he believed that "la materia mas urgente que tiene la Universidad es la del cuidado de su hazienda, cobrar lo que se le debe, pagar lo que debiere

56 Ximénez, Historia de la Provincia de Chiapa y Guatemala de la Orden de Predicadores, IV, 370; AGCA, A1, leg. 1898, exp. 12441; AGCA, A1, leg. 189o, exp. 12319.

57 Request and decree of 7 February 1689, AGI, Guatemala 136, fols. 340r-340v.

58 The professor of law decided to appoint the second-lieutenant Miguel Jerónimo González as his representative in order to procure the hearing number for him to request such documents. The power of attorney is from 9 February 1689, AGI, Guatemala 136, fols. 341v-342r.

59 By 12 February, the secretary's assistant had already notified the Audiencia that he had delivered the testimony about the queries made by the chancellor and the testimony of the council to Amézqueta's representative, AGI, Guatemala 136, fols. 342r-343r. 
[...] tomando las cuentas de los procuradores sindicos." ${ }^{\prime 60}$ Apparently, this decision was never taken.

Towards the end of that same February in 1689, Bartolomé de Amézqueta brought forth a new request to the Audiencia in which he insisted on the annulment of the council and the election of the councillors and the chancellor. He also requested the disqualification or barring of Chancellor Baños from re-election. For the professor of law, Amézqueta, the argument about the lack of councillors for the election of a chancellor that was used by Baños "y sus sequazes" was contradictory. By this time, the appointments for the vespers chairs of theology, arts, and Institutes had been made, for which "ubo y havia consiliarios para firmar los edictos que se pusieron", and, consequently, they could have carried out the necessary election. ${ }^{61}$ The lack of councillors was due to an "omiçion culpable del dicho primer rector" because not only had they been appointed, but some of them were also graduates, who had been incorporated the previous year with the support of the papal bull. He also made reference to statute six, which stated that the presence of five councillors was sufficient to appoint a chancellor. With regard to the lack of men with the necessary qualifications to fill the position of chancellor, Amézqueta presented, as an example, the option of the maestrescuela of the cathedral, Lorenzo Pérez Dardón, who had obtained his doctoral degree the previous year. In order to strengthen his argument, Amézqueta argued that, in many Spanish universities, both positions - that of the maestrescuela and that of the chancellor - were occupied by the same person because there was no regulation to prevent this from happening. To this end, he also reminded the Audiencia that, in November 1687, Dardón had been appointed as temporary chancellor. Amézqueta himself, who had been both chancellor and head of the University of Oñate at the same time, was of the opinion that it was more tolerable to allow teachers or students with probationary bachelor's degrees to be present at the election of the chancellor, as in Salamanca, "para que los hijos de los cavalleros vecinos del lugar gosasen tambien esta honra", than to withstand the infractions caused by the chancellor's behaviour. ${ }^{62}$ Amézqueta thus referred to the functioning of two institutions that he knew well: he had obtained degrees from both. In order not to diminish the strength of his argument, Amézqueta was careful not to

6o Request of 8 February 1689, AGI, Guatemala 136, fols. 294v-295v.

61 AGI, Guatemala 136, fol. 347r.

62 AGI, Guatemala 136, fol. 348r. 
mention the problems caused by students holding the position of chancellor in Salamanca. ${ }^{63}$

He also pointed out that Baños had circumvented the authority of the council when he presented his resignation directly to the vice-patron of the university. Amézqueta defended the authority of the council as the first instance at which such decisions were to be taken, as happened in the University of Salamanca, where balance among powers had prevailed.

Amézqueta put forward seven legal reasons against the continuity of Baños in the chancellorship: firstly, he referred to statute nine, which stated that a professor could not be chancellor unless he was retired, which was not the case with Baños, although he had received a dispensation from the monarch for his first year as chancellor. The second reason was that there was a requirement for two years to elapse before a person could become chancellor again, which would have prevented Baños from being elected in 1688. The third reason, which was based upon that same constitution, was the compulsory audit of every outgoing chancellor which, since Baños had not fulfilled it, rendered him ineligible to occupy the chancellorship. Fourthly, he stated that - in contravention of the statutes - the degree obtained by the chancellor at the Colegio Mayor de Nuestra Señora del Rosario in Bogotá had not been incorporated in the university. Fifthly, he declared that, in accordance with statute three, under no circumstance could a chancellor remain for more than two years in the position, legislation that had clearly not been respected by Baños. The sixth reason stated that the chancellor should have been elected unanimously by the council with the corresponding solemnity and in conformity with statute 11, i.e. with no variations or interpretation of the regulations. The last reason put forward was Baños's accumulation of no less than seven different positions in the ecclesiastical and university administrations, which made it necessary to find another candidate with fewer responsibilities who would be able to attend to university matters. In conclusion, Amézqueta asked for Juan Vázquez de Molina, the secretary of the university, to attest to the council meetings and their minutes and to issue the certifications for the graduates and for the incorporated degrees that had been made in the general course of studies to date

63 In Salamanca, compliance with the legislation was far greater. In fact, if it was not applied for some reason, the appointments were annulled, unless it was for the position of chancellor. This happened in 1564 over the appointment of Juan Vique because he was a Valencian; and, due to the consideration that the Indies were "anexas al reyno y Corona de Castilla", the appointment of Diego de Castilla, the only person from New Spain to be elected to this position, was accepted in 1571. Rodríguez-San Pedro Bezares, $L a$ Universidad Salmantina del Barroco, vol. I, 349. 
to any suitable candidate. Chancellor Baños y Sotomayor was informed of the arguments presented by Doctor Amézqueta in March of the same year. ${ }^{64}$

In response to this situation, a council meeting - apparently a plenary council - consisting of the chancellor, the maestrescuela, and all the other professors, apart from Amézqueta who was not summoned, was convened. A few days later, this council published a decree which issued an order to respect the sentence of the Audiencia with regard to the demands made by the professor of law, Amézqueta: the university was to maintain the chancellor in his position. ${ }^{65}$ The council ruled against Amézqueta's demands.

The Fight over the Chancellorship: Attrition

After a couple of months, Amézqueta heard about the report that the chancellor (Baños) had sent to the Royal Council of the Indies in 1689 regarding the quarrel that he had with professors Pedro de Ozaeta and Miguel Fernández. He decided that it was time to prepare for action: he asked the chancellor to transfer the secret minutes sent to Spain. The chancellor refused to hand them over. Amézqueta insisted by stressing the fact that the minutes had been written by his "enemigos, con testigos subditos, dependientes, atemorizados, contemplativos y temerarios". Moreover, these people were friends, a situation that can be inferred from the very words of Baños, Fernández, and Ozaeta. ${ }^{66}$ The chancellor denied having any copies because he had sent them "por distinta vía". 67

In October 1689, the Audiencia requested Baños to appoint councillors in a very different way from that stated in the regulations. Bishop Andrés de las Navas Quevedo, the oldest oidor of the Audiencia Antonio Navia y Bolaños, Chancellor José de Baños y Sotomayor, and the professors of theology, Agustín Cano and Juan Bautista Álvarez de Toledo, were directly appointed to choose the other eight councillors. This new council, which was not taken into account in the regulations, included members of the civil and ecclesiastical powers and the professors who had declared themselves to be in favour of Baños in February the previous year. The meeting was summoned for 26 October at ten in the morning and was held despite the absence of the oidor.

64 The summons is of 10 March 1689 , AGI, Guatemala 136, fols. $353 \mathrm{v}-344 \mathrm{v}$.

65 Council meeting and decree of 21 and 28 March 1689, respectively, AGI, Guatemala 136, fols. 359r-359v.

66 Request of 26 June 1689, AGI, Guatemala 136, fol. $298 \mathrm{v}$.

67 Decree of 1 July 1689 , AGI, Guatemala 136, fols. $298 \mathrm{v}-299$ r. 
The appointments - which were granted to Lorenzo Pérez Dardón, Pedro de Ozaeta, Agustín Cano, Miguel Fernández, José de Morales, José Barón de Berrieza, Baltasar de Agüero, and Antonio Padilla - were as close to the law as possible, with the sole exception of the absence of a probationary Bachelor of Medicine, which was covered by a Franciscan friar, a Master of Arts himself, like Morales. ${ }^{68}$ The minutes stated that the main topic was the appointment of the "first councillors", when it was actually the second time that such an election had taken place. This is why it comes as no surprise to find the professors who had supported Baños and the maestrescuela among the "new councillors", and this record can be interpreted either as a de facto manipulation by those close to Baños, or as an effort to follow the legislation in this "fresh start" at the university.

The election of the chancellor could finally be carried out. The councillors met, in accordance with the regulations, on 5 November that year to take the first scrutiny or vote. The meeting was quite contentious: doubts were raised about the quality of the doctors who could become chancellor and, in particular, the compatibility of the positions of maestrescuela and chancellor was called into question. Amézqueta had already brought a legal argument before the council that did not infringe the regulatory reality of Guatemala in favour of the integration of both positions into a single persona. Luckily, Baños, to whom the council forwarded the statement on 3 March of the same year, ${ }^{69}$ was present and could have easily removed the doubt that had been expressed. As on other occasions, the councillors unanimously agreed to pass the query on to the vice-patron for him to determine what was appropriate in this case.

The next meeting was held on the eighth day of that same month, ${ }^{70}$ but the council still had not received the governor's reply, so they decided to wait until 10 November, when the final election was to take place. Doctor Ozaeta emphasised this doubt, requesting proof of his vote, which was nothing more than

68 As stated in statute four, the members of the council needed to have graduated from different faculties. This is why Lorenzo Pérez Dardón was appointed as Doctor of Theology, Pedro de Ozaeta as Doctor of Canon Law, Agustín Cano as Master of Theology, Miguel Fernández as Doctor of Medicine, José de Morales as Master of Arts, José Barón de Berrieza as probationary Bachelor of Theology, Baltasar de Agüero as probationary Bachelor of Canon Law, and Antonio Padilla as probationary Bachelor of Law. Council meeting of 26 October and oath taking of 27 October 1689. AGI, Guatemala 136, fols. 308r-309v and 310v-311r.

69 AGI, Guatemala 136, fols. $353 \mathrm{v}-354$ r.

70 Council meeting of the councillors of 5 November 1689, AGI, Guatemala 136, fols. $311 v-312 v$. 
what had already been agreed upon: that the election could not be carried out until they had the vice-patron's reply. ${ }^{71}$

Finally, at a meeting on 9 November - Doctor Baños had decided to convene it early - the order of the vice-patron Jacinto Barrios Leal was read aloud: they were not to proceed with the election for the reasons and arguments expressed by the attorney of the Audiencia, Pedro de Barreda. ${ }^{72}$ The document issued by the minister enumerated the statutes that the appointment of a new chancellor would infringe: firstly, statute 11, which ordered that elections of both the councillors and the chancellor which had been carried out in a manner that was different from that stated in the regulations was to be null and void; secondly, statute ten, which re-affirmed the necessity of alternating the position between ecclesiastics and laymen and which, in order to keep it, stated that it was necessary to have three doctors from each of those ranks. ${ }^{73}$ In the attorney's opinion, the maestrescuela Pérez Dardón's appointment as chancellor was not possible because, at that time, he was the only doctor who was able to take up the position. Thus, it would not be a proper election, since there was no chance for "preferencia, nominacion o asignacion de uno entre muchos". However, the university had acknowledged up to seven doctors who had graduated at the Jesuit College, and Amézqueta, as a layman, would have also fulfilled the required alternation. However, he was not eligible because he was a professor, a condition that had been ignored in 1687 when he had been appointed chancellor in absentia. With regard to the idea of the same person occupying both the positions of maestrescuela and chancellor, the attorney stressed the incompatibility of the positions, referring the query to the monarch for a higher opinion. Once again, the election would remain suspended. ${ }^{74}$

Even though this was not supposed to constitute an attack on Amézqueta, he responded as though that had been the intention.

[...] digo que las estrañas y nuevas, $\mathrm{y}$ vehementes diligencias que hace el señor rector don Joseph de Baños y Sotomayor para prorrogarse,

71 Council meeting of the members of the council of 8 November 1689, AGI, Guatemala 136, fols. $312 \mathrm{v}-313 \mathrm{v}$.

72 Council meeting of the members of the council of 9 November 1689, AGI, Guatemala 136, fols. $313 \mathrm{v}-315 \mathrm{r}$.

73 Sarasa y Arce, Estatutos y constituciones Reales de la Regia Universidad de San Carlos de Goathemala, II, 10. The statutes stated that there must be three doctors, preferably of the status that corresponded to that year, respecting the alternation. The only possible impediment for the election was if there were no eligible doctors, not counting the outgoing doctor. AGI, Guatemala 136, fols. 316r-316v.

Attorney's reply of 5 November 1689 , AGI, Guatemala 136, fols. $315 \mathrm{v}-317 \mathrm{r}$. 
continuar o ser elegido en el oficio de rector son bien notorias a este real claustro, y esta ciudad. ${ }^{75}$

He counter-attacked by submitting a new request in which, right from the start, he made accusations against both Baños and the council: the continuity and the permanence of the chancellor were evidence enough of the breach of the university legislation. This situation went, in his view, against the law, the royal documents, and the constitutions. This was why he, as a "fiel y agradecido vasallo", sought compliance with the law: "no puedo dejar de representar a este real claustro, que la reeleccion y prorrogacion o continuacion en el oficio de rector en el dicho señor [Baños y Sotomayor] es totalmente prohibida por derecho." Once again, he resorted to statute eight, by which the chancellor had to be a graduate from the university or to have been incorporated into it. This condition, breached by Doctor Baños, who had been exempted by the sovereign in order to occupy the position, had gone too far in its interpretation, appropriation, and duration of this command. Baños was also a professor, which prevented his appointment as chancellor according to statute nine now that the year of the papal dispensation was over. Apparently, the vice-patron had decided to overlook this problem since, on more than one occasion, he had approved Baños's continuing in office, stating the benefits that this decision would bring to the monarchy. The alternative was open and the existence of incorporated degrees showed that, from 1688, there had been men who could have been appointed as councillors in order to renew the chancellorship.

Amézqueta repeated his arguments of incompatibility before the council, which he had presented before the Audiencia and which have been detailed in the pages above, adding the fact that, this time, the doctors and the authorities were approving a "tacita reeleccion". After a lengthy argument based upon the regulations, the royal commands, and the arguments brought forward by his opponents, Amézqueta introduced a reflection upon the danger of re-election, which largely explains the hostility that Baños had towards him.

[...] la dulzura de el mandar, fuese enagenar tanto los animos aun mas atentos quepa sin tiranica dominacion la templanza politica de el mando, a que se añade que comunmente durando mucho los hombres en sus oficios suelen hacerse parciales y banderizos (como se ha hecho el dicho señor rector presente, especialmente contra mi porque solicito la observancia de las constituciones). ${ }^{76}$

75 AGI, Guatemala 136 , fols. $316 r-328$ r.

76 AGI, Guatemala 136, fol. 324 r. 
Amézqueta even accused Baños "y sus sequaces" of spreading the rumour that there was no one capable of filling both positions, contradicting the doubts expressed by the council: that the statutes did not forbid this and that it did not cause any damage. On the contrary, the university would benefit from having a single jurisdictional head instead of two. Amézqueta mentioned the cases of Alcalá, Valladolid, Oñate, and Oviedo, ${ }^{77}$ although it is possible that this explanation undermined the efficacy of his arguments. The configuration of the government of these universities was quite different due to their own foundational processes. In Alcalá - which was originally a college - the chancellor ruled the university and his power was so broad that Luis Enrique RodríguezSan Pedro asserted that he was "almost omnipotent". In Valladolid, the influence over the government came from the professors, the bishop, and even the chancery, whereas in Oñate and Oviedo, the government was similar to that of Alcalá. The Crown opted for the Salamancan model for the Spanish-American studia generalia, a model that would allow it to control the universities under its patronage. ${ }^{78}$

In turn, at the American universities, the maestrescuela was concerned mostly with protocol: he granted the degrees but had no jurisdiction whatsoever in the university, in sharp contrast to Salamanca. Amézqueta recalled that, at the American universities sponsored by the king, the chancellor and the councils were to consult and obey, abide by, and fulfil the commands of the vice-patron, who was the civil authority that represented the monarch. The degree of intervention varied, depending on the strength of the union to the mother country, which was weaker in Guatemala than in Mexico, which managed to consolidate a certain resistance to the interventions of the patron and vice-patron. ${ }^{79}$ The professor of law added that, in Guatemala, there were witnesses to the way in which universities were governed in Spain: Alonso de Escobar y Loaiza, who had been a student at the College of Cuenca in

77 Amézqueta mentioned cases whose origins and organisations were different from those of Salamanca, with the exception of Valladolid. Peset has defined institutions such as those of Oñate, Oviedo, or Alcalá, as "college-universities". These were foundations created by priests from a college with a university, which had grant holders, although they allowed access to courses to day-students. In these "college-universities", the chancellor had full power over both institutional spaces: he was usually appointed by the scholars who - together with the doctors and the lecturers - constituted the councils. In order to validate their degrees as university certifications, they used to have a corresponding papal bull. See Peset, "Modelos de universidades hispanas", 120-127.

78 Rodríguez-San Pedro Bezares, La Universidad Salmantina del Barroco, I, 342-354.

79 For an example of this, see González González, "La reedición de las constituciones universitarias de México". 
Salamanca, and the Jesuit priest Aledo who was, in his own words, an expert on the matter. Amézqueta pleaded with the council for the election to be carried out in compliance with the regulations, appealing to the men at the Audiencia in the case he had brought against the appointment of Baños as chancellor. ${ }^{80}$

At the same council meeting of 9 November, Doctors José de Morales, professor of prima de artes and Mercedarian friar, ${ }^{81}$ and Miguel Fernández, professor of medicine, put forward a motion that was considered another affront to Amézqueta. According to the readers, the incorporation of Amézqueta's doctoral degree had not been registered - until then, he had been recognised as the oldest doctor in the institution - by the University of Oñate, and statute 278 stated that incorporations were to be restricted to a number of universities, among which Oñate did not appear. Doctors Morales and Fernández who had graduated at San Carlos and Alcalá, respectively - decided that the professor of law was not only to provide proof of his degree, but also the royal document that proved that his degree from the University of Oñate had been incorporated. This requirement was also extended to all graduates who had been incorporated by San Carlos. They also requested the annulment of incorporations that did not follow the regulations and their right of preference over Amézqueta. ${ }^{82}$ By requesting the recognition of Amézqueta's degree, which would bring him not just prestige but also relatively greater participation in the institution's decisions, Miguel Fernández was taking advantage of Amézqueta's political weakness, since physicians always enjoyed fewer inner privileges than the other doctors. ${ }^{83}$

The Fight over the Chancellorship: Outcomes

Hostilities continued. Amézqueta was accused of a lack of commitment in attending to lessons, he struck back by denouncing the non-payment of the fees that were due to him. His professionalism in the lessons he taught at the teacher selection processes was called into question along with the lack of students attending his lessons. Amézqueta accused Fernández and Baños of

8o He meant statutes three, four, and 9o.

81 The friar had been granted the degrees of licenciado and Doctor of Theology by proficiency in July 1688. AGI, Guatemala 136, fols. 406r-441v.

82 Request of 8 November 1689, AGI, Guatemala 136, fols. 328r-33ov.

83 Physicians were not considered suitable even to be candidates for the position of chancellor. Sarasa y Arce, Estatutos y constituciones Reales de la Regia Universidad de San Carlos de Goathemala, II, 9. 
collusion ... The electoral process for the chancellorship came to a standstill. Meanwhile, Baños and Amézqueta obstructed each other, with the former trying to remain in his position while the latter sought to remove him from it.

The election for chancellor did not take place in 1689 either. José de Baños remained as the head of the university for another year. The letter that Amézqueta sent to Charles II in 1690 explicitly stated the reasons why he declined further confrontation:

[...] si yo proseguia el pleyto del rectorado yrritaba mas al dicho doctor don Joseph de Baños y Sotomayor, al presidente y fiscal, tan declarados ya en este punto, con todos sus coligados (cuyo poder es tan digno de ser temido, al ver lo que ha pasado [...], y que no habia audiencia que hiziese justizia ni me resguardase de las violenzias (que aqui ejecuta la tirania por estar vuestra magestad tan lejos), habiendome dicho claramente vuestro oydor don Antonio de Nabia (que oy es toda la audiencia) que no podian mas por el mucho temor (a mi me pareze afectado) que tenian y tienen al presidente y sus coligados, me resolvi a dejar el dicho pleyto y tolerar la prorrogazion en la rectoria del dicho doctor don Joseph de Baños y Sotomayor, creyendo con este retiro lograr alguna quietud, por lo menos, en el interin que llega el remedio que tanto combiene como deseamos $[\ldots]$.

By this, he meant the renewal of the position of chancellor. ${ }^{84}$

Even though Amézqueta did not manage to get the chancellor - who would remain in the position until his death in 1696 - dismissed, he did indeed manage to inform the monarch about the political organisation of the capital of Guatemala. In 1693, both Amézqueta and Ozaeta took up their respective positions as oidores, a royal favour bestowed upon them after five years of lecturing in San Carlos. The royal appointment in favour of Amézqueta was the probable reason for the president of the Real Audiencia supporting Baños over him in the argument regarding the chancellorship: the legist had stated what - in his view - was a breach of the law; the president, for his part, was trying to make sure that Amézqueta had no support when he occupied the prima chair of law. Amézqueta was later sent to the reducciones de indios, ${ }^{85}$ and, with this move,

84 AGI, Guatemala 373, fols. 334r-334v.

85 A "reduction", or "reducción de indios", was the process of congregating and so bringing together several dispersed indigenous populations to a common place. The ultimate aim of this was to instil them with policía and unity in the faith, and so it was a method of territorial control. 
the authorities succeeded in distancing Baños's main detractor. In 1697, the professor of law was involved in the mutiny of the city militia. The ensuing royal visitation that determined the degree of involvement that he and Pedro de Ozaeta had in the event would open a new chapter in their participation in the public life of Guatemala; and Professor Amézqueta managed to get granted - albeit for just a few hours - the position of president of the Real Audiencia. ${ }^{86}$

All the men involved in the contest for the chancellorship were part of a complex system of relations between the local elite. There were no sides to this conflict. Conversely, there was a well-set power structure whose members saw ministers sent by the king as a threat to their management of the university and local politics. The numerous positions and favours that Charles II had granted Amézqueta, Ozaeta, and Fernández - the three professors who had been appointed in 1687 - made them potentially dangerous to the social and political control of Guatemala. ${ }^{87}$

Nevertheless, they had to be absorbed and incorporated into the local power network, as was expressed in the conditions of the royal command that had sent them to Guatemala. The personal context of each of them explains, in large part, the different strategies that they used to establish themselves and survive in the new context. Both Ozaeta and Fernández submitted to the established order, which demonstrates their capacity to analyse the political reality as well as their resilience in encountering a new social context. Even though the way in which they related to local authorities differed, the strategy they both displayed during the period of confrontation over the chancellorship was to become politically close to Baños. Amézqueta's tactics were very different. He decided to break the wall that separated him from the established structure of power in order to gain access to it; his Cerberus, Doctor Baños, had a large network of allies at all levels of the hierarchy of public power which allowed him - when the confrontation began - to gain the unanimous support of the rulers. The connections that university boards had with different local power

86 Álvarez Sánchez, "De la cátedra a la conjura", 117-155.

$87 \quad$ Amézqueta was acknowledged as the oldest doctor, appointed dean of his faculty and tenured professor of prima de leyes, and he also obtained a five-year position as judge of the Audience. Ozaeta became the dean of his faculty, tenured professor of the chair prima of canon law, and obtained the position of judge of the Audience after five years of teaching. Fernández was also made dean, tenured in the chair prima of medicine, and given a place at the College of the King's Physicians after five years of teaching. He was never able to take up this last office because the College of the King's Physicians was not established in Guatemala until 1793. AGCA, A1, leg. 1883, exp. 12237, fols. 81r-88v; Lanning, Reales Cédulas de la Real y Pontificia Universidad de San Carlos de Guatemala, 71-72 and 74-82. 
groups were replicated in every city - both in America and in the Spanish peninsula - where a studium generale or a college with the ability to grant degrees was founded, as shown by Enrique González González. ${ }^{88}$

Doctor Baños came to be the link that connected university men with the rest of the civil and ecclesiastical institutions in the capital of Guatemala. Within the cathedral structure, Baños filled the position of dean of the cathedral, the rank immediately below that of bishop, and so was directly connected both to him and the maestrescuela even before attaining the chancellorship. The successive accumulation of positions, a characteristic common to all the religious ministers at the time, linked him both to the monastic orders and to the Inquisition. His fame as a preacher won him important positions such as that of vicar general of the bishopric. Arriving at the Cathedral of Guatemala as a canon in 1670 from Santa Fé de Bogotá, he ascended the internal structure of the cathedral council of canons until he reached the deanship in 1682. Unable to obtain a bishopric, he found promotion and a reserve of power at the university which granted him far greater political reach. Before achieving this, the religious orders had been the target of his attacks: at the beginnings of the foundation of the studium generale, Baños, who was holding the office of cathedral superintendent (chantre), had undergone the teacher selection process for a chair which was eventually granted to the Mercedarian Diego de Rivas. His immediate reaction had been to write to the king. These operations were not more important than the familial bond that connected him to one of the members of the Royal Council of the Indies, so he was granted the royal favour of being appointed as a tenured professor of the prima chair of theology and the first chancellor of San Carlos. ${ }^{89}$

The chancellorship placed him in a position from which he could only broaden his political relations, the first and the most important of which was with the governor, who was also the president of the Real Audiencia and the vice-patron of San Carlos. Enrique Enríquez de Guzmán, as well as his successor, Jacinto Barrios Leal, enjoyed a more than cordial relationship with Baños, which is evident in the analysis of the opinions and the decree issued by the attorney, Pedro de Barreda, who constantly showed his support for Baños to remain as chancellor. Barreda had studied and taught at the Royal University of Mexico, and became the attorney of the Real Audiencia of Guadalajara before

88 González González, El poder de las letras.

89 In Doctor Baños's family background, we can find crown ministers in both America and Spain. His genealogy included men in the Real Audiencias and even a member of the Royal Council of the Indies, his brother-in-law, AG I, Indiferente General 206, N. 52, and Álvarez Sánchez, Patronazgo y educación, 209. 
he was sent to Guatemala..$^{90}$ The Mexican attorney tried to return to his home country as an oidor but, when he was unable to accomplish this, he worked on strengthening his local political relations, both within the Audiencia - with its president and the oidores - and with some of the main families in Guatemala.

Within the university, Doctor Baños gained allies: sometimes they were forced to become his allies for fear of his political reach as chancellor, such as the Dominican Agustín Cano, sometimes they became allies of their own volition, such as the canonist Ozaeta, and sometimes they did so because of the affinity of their professional interests, such as the priest González de Maeda. From the beginning, Baños tried to surround himself with members of the secular clergy and ministers of the Inquisition, be they doctors of the Jesuit College or friars, and he filled the council with them. At the few sessions held by this governing body, its members always proved to be in favour of Baños remaining. At the commands of the patron and the vice-patron, none of them, not even the protomedic of the city, José Fernández Parejo - whose connection to the chancellor still remains to be determined -, ever called Baños's power into question.

He carefully chose the members of the council of deputies: men who would not pose a threat and men who would allow him to strengthen his connections to the civil power. These men included Professors Lorenzo Soriano de la Madriz Paniagua, Antonio Dávila Quiñones, and Baltasar de Agüero - his godson -, all of whom were attorneys of the Audiencia, the Mercedarian Diego de Rivas, official assessor of the Inquisition, and the Bachelor Lorenzo González de Maeda, whom Baños himself had appointed as professor of the Mexican language (Pipil/Náhuat). The public votes cast at the 1688 council meetings show that Baños controlled the government bodies: Agustín Cano preferred to support the continuity of the chancellor and José de Morales, who would replace Cano after receiving the chancellor's appointment, also gave a favourable opinion of Baños.

It is clear that Doctor Amézqueta faced a large and varied power group within which Baños enjoyed a pre-eminent position. The chancellor had the possibility of closing each and every door that Amézqueta might knock upon in order to "buscar justicia" and abide by the university legislation. After three years of confrontations within and outside of the university, in Guatemala and in the metropolis, the rivalry between them developed into mutual hostility. Bartolomé de Amézqueta gave up his former eagerness to have Baños dismissed, not only because the latter had insurmountable support, but also 
because his personality and his occupations made it impossible for him to resign from a position that had brought him so many benefits,

El dean doctor don Joseph de Baños y Sotomayor no es codizioso, tiene muy bastante literatura, es muy buen predicador y theologo, asiste con mucho cuydado a su catedra, pero la ambizion de mandar lo ciega, y no es esto lo peor, sino el genio que tiene tan amigo de mandar despoticamente y solamente por su arbitrio, sin sujetarse a ley, a lo qual se junta la multitud de ofizios. ${ }^{91}$

Despite the fact that Amézqueta fought to expel Baños from the chancellorship, he never explicitly stated his own wish to obtain the position, although he would eventually come to fill it in the year $1708 .{ }^{92}$

The appointment of a chancellor would not, however, be regularised after Baños's death in 1696: the new chancellor, Juan de Cárdenas - who came after Lorenzo Pérez Dardón's term as maestrescuela -, likewise remained in the position for several years, also until his death. Jacinto Barrios Leal, governor and president of the Real Audiencia, had decided to refer the query that the council had made regarding the possible incompatibility of simultaneously holding the positions of chancellor and maestrescuela in Pérez Dardón's case to the king. While waiting for the monarch's reply to arrive, a new governor and president of the Real Audiencia, Gabriel Sánchez de Berrospe, was appointed, and he sent a new query to the monarch in November 1696, after Baños's death. In that period, he appointed Juan de Cárdenas as temporary chancellor and Diego de Rivas - who had been appointed as a finance deputy by Baños - as temporary professor of the prima chair of theology. The king would not reply to the queries until 6 March 1700, almost five years after the first query had been sent, and his answer was that the appointment of a chancellor had to be regularised according to the legislation in force. ${ }^{93}$ Both appointments of a temporary chancellor during these first decades of university life would go to the maestrescuelas, Pérez Dardón and Cárdenas, by order of the vice-patron, making the secular clergy's control of the university government clear, a situation that would continue to be the norm throughout the 18 th century.

91 AGI, Guatemala 373 , fol. $35^{8 \mathrm{v}}$.

92 AGCA, A1, leg. 45, exp. 1140.

93 Royal document of 6 March 1700, AGCA, A1, leg. 1882, exp. 12236, fols. 83r-84r; Lanning, Reales Cédulas de la Real y Pontificia Universidad de San Carlos de Guatemala, 114-115. 
Within this context, the councils were unable to act independently of public powers in the government of the studium generale. The state machinery and the political culture were adapted to the context of Guatemala, where the manners and relations had been well established with the arrival of the foundational documents of San Carlos. The university, however, not only symbolised a new space for the development of the local power structure, it was also a space for the formation of the political and intellectual elite. In Salamanca and in America, the balance of power and the prestige of the universities determined the extent of the conflict between the two groups. All social sectors became concerned about the benefits that could be gained from establishing and keeping a cordial relationship with the universities. On the other hand, the university had social recognition, and used it to obtain positions for its graduates.

With regard to the social role of the University of San Carlos, its graduates were recruited into the bureaucracy of the Real Audiencia, both in ecclesiastical and civil positions. Naturally, its graduates originally came from Mexico and Lima, but once the granting of certification was consolidated, the university graduates mostly remained within the Audiencia's territories. In fact, some locals, such as Bishop Rivas - the first prelate to have been born in the city of Guatemala - attained important positions. As a result of a recent study of the Inquisition and the commissions of the Real Audiencia, ${ }^{94}$ it has been confirmed that university graduates established connections with this institution: the chancellors also held the positions of commissioners of the capital, and many graduates did the same in other cities, towns, villages, and seaports. The student population of the vice-regal period is still being studied, but we can already affirm that a minimum proportion of the students obtained the levels of graduate, master, and doctor that would have allowed them to hold other positions both within and outside of the university. Most of the graduates had to look for a career either in the clergy or in other areas: physicians, lawyers, theologians, and artists could all work for private individuals in need of their services. However, a constant complaint of the authorities concerned the students' lack of interest in attending courses. The students had virtually no involvement in the university's decisions: the student vote - which was practised in Mexico, although eventually abolished, just like in Salamanca - never appeared in the legislation of San Carlos, which is why the students, under the 
chancellor's jurisdiction, had barely any incentive to actively participate in the internal politics of the university. This, however, did not seem to cause any tension between the authorities, lecturers, or students. Despite this, I do not rule out the possibility of new findings in this matter, once a detailed study of the students who attended this universitas is completed.

The apparent weakness of the Spanish monarchy and its legal order is not, however, as it seems. The configuration of power groups in cities that were far from the metropolis - such as Guatemala - was a process that the Crown paid constant and close attention to: the choice of the claustral mode of royal patronage is proof of this. The presence of the Crown - and its ministers - in this university did not take place gradually, as in the case of Salamanca, but occurred blatantly from the very start. The vice-patron - as the king's representative - and the Real Audiencia were the organs that took the decisions during the conflict over the chancellorship. The files sent by Baños and Amézqueta were received in the Royal Council of the Indies, and, even though this authority did not respond immediately, it did deal with other university matters, such as the auditing of its accounts. Only in 1696 did the highest authority consult the monarch about filling the two vacant positions left when Baños died. On a royal document of the year 1700, the sovereign barely mentioned the matter about the chancellorship and ordered the regulations of San Carlos to be precisely observed. Nevertheless, he decided not to punish any of those involved in the strife in light of the fact that Doctor Baños had already died and that Doctor Amézqueta had been sent to the reductions, and also, quite possibly, because of the assumed legal plurality of the Indies.

\section{Acknowledgements}

I would like to thank Cristina Ratto for the revisions and suggestions she made: her comments helped improve the final presentation of this complex piece of history. I would also like to thank José Luis Egío García for his detailed reading of the text and for all of his suggestions. Finally, I thank Amanda Zamuner and Soledad Pérez for the first translation of this article.

\section{Bibliography}

\section{Manuscripts}

Archivo General de Indias, Sevilla (AGI), Audiencia de Guatemala 136. AGI, Guatemala 137 . 
AGI, Guatemala 154.

AGI, Guatemala 373 .

AGI, Contratación 579o, L. 3.

AGI, Indiferente General 124, N. 82.

AGI, Indiferente General 127, N. 105 .

AGI, Indiferente General 135, N. 25.

AGI, Indiferente General 206, N. 52.

Archivo General de Centroamérica, Guatemala (AGCA) A1, leg. 45, exp. 1140.

AGCA, A1, leg. 1882, exp. 12236.

AGCA, A1, leg. 1883, exp. 12237.

AGCA, A1, leg. 1885, exp. 12245 .

AGCA, A1, leg. 1889, exp. 12300.

AGCA, A1, leg. 189o, exp. 12319.

AGCA, A1, leg. 1898, exp. 12441.

AGCA, A1, leg. 1898, exp. 12442.

AGCA, A1, leg. 1940, exp. 12865.

AGCA, A1, leg. 1940, exp. 12866.

AGCA, A1, leg. 1940, exp. 12874.

\section{Printed Sources}

Irungaray, Ezequiel, Índice del Archivo de la Enseñanza Superior de Guatemala, Guatemala 1899 (repr. ed. Zavala Cordero, Jaime, Guatemala 1962).

Palafox y Mendoza, Juan de, Constituciones para la Real Universidad de México, México 1645 (repr. eds. González González, Enrique and Víctor Gutiérrez, México 2017).

Sarasa y Arce, Francisco de, Estatutos y constituciones Reales de la Regia Universidad de San Carlos de Goathemala, Guatemala 1681 (repr. eds. Arce, Manuel José, Augusto Cazali Ávila and Francisco Albízures Palma, Guatemala 1976).

Ximénez, Francisco, Historia de la Provincia de Chiapa y Guatemala de la Orden de Predicadores, 5 vols., Tuxtla Gutiérrez 1993.

\section{Literature}

Álvarez Sánchez, Adriana, "Los libros de claustros como fuente para estudiar la vida universitaria. 1701-1705", in Pérez Puente, Leticia and María de Lourdes Alvarado (eds.), Cátedras y catedráticos en la historia de las universidades e instituciones de educación superior en México, México 2005, 387-401.

Álvarez Sánchez, Adriana, "Debate y reforma del método de estudios de la Real Universidad de San Carlos de Guatemala del siglo XVIII", in Revista Iberoamericana de Educación Superior 5 (2011), 82-99.

Álvarez Sánchez, Adriana, "El imperio y el gremio universitario de Guatemala en el siglo XVII", in Sémata. Ciencias Sociais e Humanidades 23 (2011), 189-209. 
Álvarez Sánchez, Adriana, "De la cátedra a la conjura. Vida universitaria y vida política de tres funcionarios de la monarquía hispánica en Guatemala", in Pavón Romero, Armando (ed.), Promoción universitaria en el mundo hispánico. Siglos XVI al XX, México 2012, 117-155.

Álvarez Sánchez, Adriana, "Los grados de la Real Universidad de San Carlos de Guatemala. Siglos XVII-XVIII", in Correa Ballester, Jaime and Mariano Peset Reig (eds.), Matrículas y lecciones. XI Congreso Internacional de Historia de las Universidades Hispánicas, vol. 1, Valencia 2012, 193-216.

Álvarez Sánchez, Adriana, "Las cátedras de lenguas indígenas en la Universidad del Reino de Guatemala. Siglos XVII-XIX”, in Estudios de Cultura Maya 46 (2014), 119-139.

Álvarez Sánchez, Adriana, Patronazgo y educación. Los proyectos de la Real Universidad de San Carlos de Guatemala (1619-1687), México 2014.

Álvarez Sánchez, Adriana, "El Colegio de Santo Tomás de Aquino de Guatemala: un proyecto inacabado (1653-1676)”, in Benavides Silva, Fabián Leonardo, Eugenio Martín Torres Torres and Andrés Mauricio Escobar Herrera (eds.), Orden de Predicadores. 800 años. II. Los dominicos en la educación, siglos XVI-XXI, Bogotá 2018, 43-66.

Álvarez Sánchez, Adriana, "Interacciones y tradiciones: los estatutos de las universidades reales de América”, in González González, Enrique, Leticia Pérez Puente and Hugo Casanova (eds.), Universidades de América: ayer y hoy, México 2020, 45-89.

Álvarez Sánchez, Adriana, "La Inquisición en el territorio de la audiencia de Guatemala (siglos XVI-XIX)”, in Ciaramitaro, Fernando and Miguel Rodrigues Lourenço (eds.), Historia imperial del Santo Oficio (siglos XV-XIX), México and Murcia [forthcoming publication].

Burke, Peter and Ronald Po-Chia Hsia (eds.), Cultural Translation in Early Modern Europe, New York 2007.

Castañeda Paganini, Ricardo, Historia de la Real y Pontificia Universidad de San Carlos de Guatemala: época colonial, Guatemala 1947.

Ciudad Suárez, María Milagros, Los dominicos, un grupo de poder en Chiapas y Guatemala. Siglos XVI y XVII, Sevilla 1996.

Duve, Thomas, "The School of Salamanca. A Case of Global Knowledge Production", in Duve, Thomas, José Luis Egío and Christiane Birr (eds.), The School of Salamanca: A Case of Global Knowledge Production (Max Planck Studies in Global Legal History of the Iberian Worlds, vol. 2), Leiden 2021, 1-42.

González González, Enrique, “Oidores contra canónigos. El primer capítulo de la pugna en torno a los estatutos de la Real Universidad de México (1553-1570)", in Bernal, Beatriz (ed.), Memoria del IV Congreso de Historia del Derecho Mexicano, vol. 1, México 1988, 455-477.

González González, Enrique, "La reedición de las constituciones universitarias de México (1775) y la polémica antiilustrada", in Alvarado, Lourdes, Tradicióny reforma en la Universidad de México, México 1994, 57-108. 
González González, Enrique, “Era pontificia la Real Universidad de México?”, in González González, Enrique and Leticia Pérez Puente (eds.), Permanencia y cambio I. Universidades hispánicas, 1551-2001, México 2005, 53-81.

González González, Enrique, El poder de las letras. Por una historia de las universidades de la América hispana en el periodo colonial, México 2017.

Lanning, John Tate, The University in the Kingdom of Guatemala, New York 1955.

Lanning, John Tate (ed.), Reales cédulas de la Realy Pontificia Universidad de San Carlos de Guatemala, Guatemala 1954.

Martínez Durán, Carlos, Las ciencias médicas en Guatemala: origen y evolución, Guatemala 1941.

Mata Gavidia, José, Panorama filosófico de la Universidad de San Carlos al final del siglo XVIII, Guatemala 1948.

Mata Gavidia, José, Temas de filosofía moderna sustentados en 1785 en la Universidad de San Carlos de Guatemala, Guatemala 1949.

Mata Gavidia, José, Fundación de la Universidad de Guatemala, 1548-1688, Guatemala 1954

Pardo, José Joaquín, Efemérides de la Antigua Guatemala, Guatemala 1944.

Pavón Romero, Armando (ed.), Universitarios en la Nueva España, México 2003.

Pérez Puente, Leticia, "Los inicios del Seminario de Nuestra Señora de la Asunción de Guatemala, 1598-1620", in Hispania Sacra 129 (2012), 187-210.

Peset, Mariano, "Poderes y Universidad de México durante la época Colonial”, in Peset, José Luis (ed.), La ciencia moderna y el Nuevo Mundo, Madrid 1985, 57-84.

Peset, Mariano, "La adaptación del modelo salmantino en las fundaciones de Lima y México (1551)" in Rodríguez-San Pedro Bezares, Luis Enrique and Juan Luis Polo Rodríguez (eds.), La Universidad de Salamanca y sus confluencias americanas, Salamanca 2002, 37-62.

Peset, Mariano, "Modelos de universidades hispanas", in Peset, Mariano, Obra dispersa, México 2012, 120-127.

Rodríguez Cabal, Juan “Universidad de Guatemala. Su origen-fundación-organización”, in Anales de la Sociedad de Geografía e Historia de Guatemala, 26: 2 (1952), 143-242; and 28:1 (1957), 1-4.

Rodríguez Cruz, Águeda, Salmantica docet. La proyección de la Universidad de Salamanca en Hispanoamérica, 2 vols., Salamanca 1977.

Rodríguez San-Pedro Bezares, Luis Enrique, La Universidad Salmantina del Barroco, periodo 1598-1625,vol. 2, 3 vols., Salamanca 1986.

Sáenz de Santa María, Carmelo, Historia de la educación jesuítica en Guatemala, Madrid / Guatemala 1978.

Schäfer, Ernesto, El Consejo Realy Supremo de las Indias. Su historia, organizacióny labor administrativa hasta la terminación de la casa de Austria, 2 vols., Valladolid 2003.

Tau Anzoátegui, Víctor, ¿Quéfue el Derecho Indiano?, Buenos Aires 1982. 
Tau Anzoátegui, Víctor, Casuismo y sistema. Indagación histórica sobre el espíritu del Derecho Indiano, Buenos Aires 1992.

Tau Anzoátegui, Víctor, "La disimulación en el Derecho Indiano", in Tau Anzoátegui, Víctor, El jurista en el Nuevo Mundo. Pensamiento. Doctrina. Mentalidad, Frankfurt am Main 2016, 223-243. 